\title{
Rapid PCR-based assay for Sclerotinia sclerotiorum detection on soybean seeds
}

\author{
Edilaine Mauricia Gelinski Grabicoski ${ }^{1}$, David de Souza Jaccoud Filho ${ }^{1 *}$, Marcos Pileggi², Luciane Henneberg ${ }^{1}$, Marcelo Luiz Cunha
} Pierre $^{1}$, Cláudio Mauricio Vrisman ${ }^{1}$, Audrei Nisio Gebieluca Dabul1,3

\author{
${ }^{1}$ State University of Ponta Grossa - Dept. of Plant Science \\ and Plant Pathology, Av. Gal. Carlos Cavalcanti, 4748 - \\ Uvaranas - 84030-900 - Ponta Grossa, PR - Brazil. \\ ${ }^{2}$ State University of Ponta Grossa - Dept. of Structural, \\ Molecular and Genetic Biology. \\ ${ }^{3}$ Arkansas State University/Arkansas Biosciences Institute - \\ State University, AR 72467 - USA. \\ *Corresponding author <dj1002@uepg.br> \\ Edited by: Emerson Medeiros Del Ponte
}

Received November 29, 2013

Accepted June 17, 2014
ABSTRACT: Caused by Sclerotinia sclerotiorum, white mold is an important seed-transmitted disease of soybean (Glycine max). Incubation-based methods available for the detection and quantification of seed-borne inoculum such as the blotter test, paper roll and Neon-S assay are time-consuming, laborious, and not always sensitive. In this study, we developed and evaluated a molecular assay for the detection of $S$. sclerotiorum in soybean seeds using a species-specific PCR (polymerase chain reaction) primer set and seed soaking (without DNA extraction) for up to $72 \mathrm{~h}$. The PCR products were amplified in all the samples infected with the pathogen, but not in the other samples of plant material or the other seed-borne fungi DNA. The minimum amount of DNA detected was 10 pg, or one artificially infested seed in a 400seed sample (0.25\% fungal incidence) and one naturally infected seed in a 300-seed sample $(0.33 \%$ incidence). The PCR-based assay was rapid $(<9 \mathrm{~h})$, did not require DNA extraction and was very sensitive.

Keywords: white mold, dissemination, soaking seeds, diagnostic

\section{Introduction}

Sclerotinia sclerotiorum (Lib.) de Bary is one of the most devastating and widespread fungal pathogens, affecting over 400 plant species worldwide. It is well known as the cause of white mold, a disease of economic concern to soybean (Glycine max) production that can reduce yield by as much as $40 \%$ when weather conditions are favorable, such as rainy seasons and mild temperatures (Boland and Hall, 1994; Saharan and Mehta, 2008; Peltier et al., 2012). The fungus produces a resistant structure (sclerotium) that allows it to survive in the soil for up to five years (Adams and Ayers, 1979; Steadman, 1983). The pathogen is transmitted by seeds, which are considered to be the main source of inoculum and an important dissemination agent (Adams and Ayers, 1979; Steadman, 1983; Yang et al., 1998).

Seed health tests available for the detection of $S$. sclerotiorum in soybean seeds are based on seed incubation (Carvalho-Vieira and Machado, 2002; Napoleão et al., 2006; Brasil, 2009), which requires a large space, is not time-effective, and may lack sensitivity (Blakemore and Reeves, 2002; Carvalho-Vieira and Machado, 2002; Jaccoud-Filho et al., 2002; ISTA, 2008; Henneberg et al., 2011).

Alternatives, such as PCR-based assays, are time-effective, versatile, and sensitive in identifying low quantities of DNA and amplifying specific products (Mullis and Faloona, 1987); they have also been used to detect several seed-borne pathogens (Audy et al., 1996; Blakemore and Reeves, 2002; Jaccoud-Filho et al., 2002; Taylor et al., 2006; Landa et al., 2007; Kulik, 2008; Jaccoud-Filho and Dabul, 2011). Due to its high specificity, PCR has been used to identify races of some fungal species, as shown by Jiménez-Gasco and Jiménez-Díaz (2003) for some races of Fusarium oxysporum f. sp. ciceris. However, partial detection of the pathogen population is undesirable for a spe- cies-specific detection test, i.e. it detects only some races, isolates or strains (Carvalho-Vieira and Machado, 2002).

Some protocols for detecting plant pathogens do not require DNA extraction. Instead, seeds or plant parts are soaked, and the suspension is used as the source of the DNA template (Jaccoud-Filho et al., 2002). Such a technique has never been developed and tested for the detection of $S$. sclerotiorum in soybean seeds. Hence, this study aimed to develop and test a PCR-based method to detect $S$. sclerotiorum in both artificially infested and naturally infected soybean seeds using the seed-soaking procedure, with regard to specificity, sensitivity and execution time as compared with traditional methods.

\section{Materials and Methods}

\section{Fungal strains}

The following samples and fungi were used: sclerotia of $57 \mathrm{~S}$. sclerotiorum isolates collected from infested soybean fields; pure cultures of Sclerotium rolfsii, Trichoderma sp., Aspergillus sp., Penicillium sp., Macrophomina phaseolina, Colletotrichum sp. and Rhizopus sp.; tegument of soybean seeds infected by Peronospora manshurica; and DNA of other fungi commonly found in soybean seeds (Cercospora sojina, Phomopsis sojae, Aspergillus sp., C. kikuchii, Fusarium sp. and Colletotrichum truncatum).

\section{Seed samples}

Clean seeds of the CD 206 RR cultivar (Lot 408) were collected in a soybean field in Lapa $\left(25^{\circ} 46^{\prime} 15^{\prime \prime} \mathrm{S}\right.$, 49 43' $8^{\prime \prime}$ W), in the state of Paraná (PR), Brazil. Naturally infected seed samples were collected from a soybean field in Pinhão, PR (25⒋ $41^{\prime} 44^{\prime \prime}$ S, 51 $39^{\prime} 35^{\prime \prime}$ W), during the 2010-11 season, which presented a mean of 258 sclerotia $\mathrm{m}^{-2}$, from an average of four collected points of $0.25 \mathrm{~m}^{2}$ of soil each $(0.5 \mathrm{~m}$ in length and width and 0.05 $\mathrm{m}$ in depth), which was sifted using a 10 mesh sieve (2 
$\mathrm{mm}$ ). In this field, around 1,000 infected BMX Apolo RR plants were assessed at the R5.5/R6 (full seed) phenological stage (Fehr and Caviness, 1977). Each plant was scored for three categories of severity of disease: (i) less than $10 \%$ (PI-10), (ii) around $50 \%$ (PI-50), and (iii) greater than $80 \%$ (PI-80) (Juliatti et al., 2013). During crop maturation, seeds of plants from each category of severity were manually collected and stored in paper bags at $20^{\circ} \mathrm{C}$. Both the clean and naturally infected seed samples were evaluated using three incubation-based seed-health detection methods (blotter-test, paper roll, and Neon-S) to detect and quantify fungal incidence (percentage of infected seeds) at the individual seed level (Machado and Langerak, 2002; Napoleão et al., 2006; Brasil, 2009). To obtain the artificially infested seed samples, clean seeds were placed on five day-old $S$. sclerotiorum pure cultures (I-45 isolate) grown in PDA plates. A 400-seed sample was used, in accordance with international standards (ISTA, 2008). For the $100 \%$ infestation level, the seeds were exposed to the fungus at seven inoculation times: $0,4,8,12,24,48$, and $72 \mathrm{~h}$. The seeds exposed to the maximum time were pooled with the clean seeds in increasing proportions to generate seven infestation levels: $0.25 \%, 1 \%, 2.5 \%, 5 \%, 25 \%, 50 \%$ and $75 \%$.

\section{Seed-soaking}

Clean, naturally infected, and artificially infested seeds were soaked in ultrapure sterilized water at a ratio of 100 seeds $/ 100 \mathrm{~mL}$ of water in hermetic plastic packaging. The packages were stored at $4{ }^{\circ} \mathrm{C}$, and $1 \mathrm{~mL}$ of seed-soaking liquid was collected at $0,1,2,3,4,5,6,7$, $8,12,24,48$, and $72 \mathrm{~h}$. These aliquots were stored at -20 ${ }^{\circ} \mathrm{C}$ until use (no more than seven days).

\section{DNA extraction}

Mycelia were obtained from the sclerotia and pure culture discs of the fungal strains. The latter were grown at room temperature in potato dextrose broth (PDB) in an orbital shaker for approximately five days. The mycelia were collected by filtration with sterilized germitest paper and were then lyophilized. Trifoliate leaves from soybean seedlings cultivated on sterilized substrate were cleaned in ultrapure sterilized water. The lyophilized mycelia, plant material, and tegument of soybean seeds infected with $P$. manshurica were macerated using a porcelain mortar and pestle with liquid nitrogen for DNA extraction. The DNA was extracted using the CTAB method (Murray and Thompson, 1980), which was modified so as not to use $\beta$-mercaptoethanol and PVP 40. All the DNA samples were treated with RNAse A $\left(10 \mu \mathrm{g} \mathrm{mL} \mathrm{m}^{-1}\right)$, diluted in TE buffer (10 mM Tris-Cl, $\mathrm{pH}$ 8.0; and $1 \mathrm{mM}$ EDTA, $\mathrm{pH} 8.0$ ) to $10 \mathrm{ng} \cdot \mu \mathrm{L}^{-1}$ and stored at $-20{ }^{\circ} \mathrm{C}$ until use (Sambrook and Russell, 2001). To test whether the detection of $S$. sclerotiorum by PCR could be made without DNA extraction, approximately $0.2 \mathrm{mg}$ of S. sclerotiorum sclerotia and $0.1 \mathrm{mg}$ of mycelia were collected from a pure culture and heated with $100 \mu \mathrm{L}$ of TE buffer at $95{ }^{\circ} \mathrm{C}$ for $10 \mathrm{~min}$.

\section{PCR protocol optimization}

The DNA of the 57 isolates of $S$. sclerotiorum, the other fungi, and soybean plants were used to test the specificity of the SSFWD/SSREV primers targeting $S$. sclerotiorum (Freeman et al., 2002). PCR amplification was performed with ultra-pure water (Sigma, USA) in 50 $\mu \mathrm{L}$ reactions containing: $1.5 \mathrm{U}$ Taq DNA polymerase, 10 $\mathrm{mM}$ Tris- $\mathrm{HCl}, 50 \mathrm{mM} \mathrm{KCl}, 1.5 \mathrm{mM} \mathrm{MgCl}, 0.005 \%$ gelatin, $0.2 \mathrm{mM} \mathrm{dNTP}$, stabilizers, $0.2 \mu \mathrm{M}$ of each primer, and the tested sample [10 ng of genomic DNA (fungal or soybean)], or $2 \mu \mathrm{L}$ of seed-soaking liquid, or $2 \mu \mathrm{L}$ of mycelium/sclerotia boiled suspensions, or 10-fold serial dilution of $S$. sclerotiorum DNA [100 ng to $1 \mathrm{fg}$ (isolate I-45)]. Clean, naturally infected and artificially infested samples were used. The PCR conditions were: an initial step at $95{ }^{\circ} \mathrm{C}$ for $10 \mathrm{~min} ; 30$ cycles at $94^{\circ} \mathrm{C}$ for $30 \mathrm{~s}$; at 52 ${ }^{\circ} \mathrm{C}$ for $1 \mathrm{~min}$ and at $72^{\circ} \mathrm{C}$ for $1 \mathrm{~min}$; and a final extension at $72{ }^{\circ} \mathrm{C}$ for $10 \mathrm{~min}$. The ITS4/ITS5 primer pair directed to the rDNA (White et al., 1990) was used to evaluate the amplification quality of the fungi and soybean DNA. Each PCR amplification was performed as previously described, using $10 \mathrm{ng}$ of DNA as a sample. The reaction conditions were: an initial step at $95{ }^{\circ} \mathrm{C}$ for $10 \mathrm{~min} ; 30$ cycles at $94{ }^{\circ} \mathrm{C}$ for $30 \mathrm{~s}$; at $42{ }^{\circ} \mathrm{C}$ for $2 \mathrm{~min}$ and at $72{ }^{\circ} \mathrm{C}$ for $2 \mathrm{~min}$; and a final cycle at $72{ }^{\circ} \mathrm{C}$ for $10 \mathrm{~min}$ (White et al., 1990). To analyze the PCR amplification, $2 \mu \mathrm{L}$ of the PCR reaction were mixed with $6 \mu \mathrm{L}$ of the loading buffer [0.25\% bromophenol, $30 \%$ glycerol in distilled $\mathrm{H}_{2} \mathrm{O}$, fluorescent nucleic acid dye GelRed 15X] and were loaded onto $1 \%$ agarose gels in 1X TBE buffer (Sambrook and Russell, 2001). The I-45 isolate DNA was used as a positive control and a reaction containing no template DNA was used as a negative control.

\section{Results and Discussion}

Using the SSFWD/SSREV primer set, a specific 278 bp product was amplified only for the DNA of the $S$. sclerotiorum isolates and not for the other fungi in which the DNA was of good quality, based on ITS amplification (data not shown). This corroborated previous findings (Freeman et al., 2002) and demonstrated the specificity of the PCR-based method, an important requirement for specific detection (Machado and Langerak, 2002). The same product size was amplified when mycelia suspension and sclerotia were assayed (no DNA extraction) (Figure 1).

For the artificially infested seeds, the DNA was amplified for the aliquots that were taken during the first $12 \mathrm{~h}$ of soaking. For incubation times longer than this the amplification was weak or absent (Figure 2), which may have been due to inhibition of the reaction by compounds released from the seeds (Mullis and Faloona, 1987). Potential inhibitors include lipids and cellulose, which have been associated with false, negative PCR results (Rossen et al., 1992; Schrader et al., 2012).

DNA inhibition was highest for the seed sample with the highest infestation level (Figure 2A), which had 


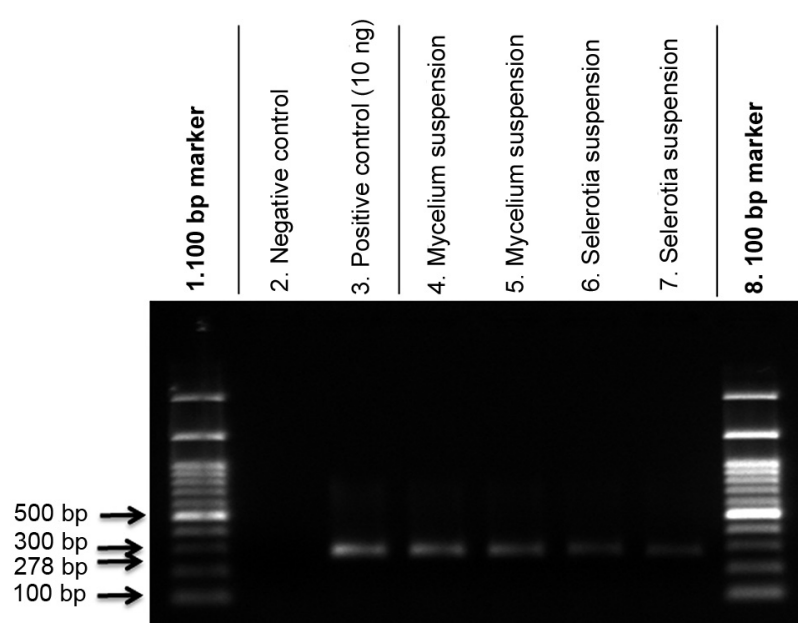

Figure 1 - PCR (polymerase chain reaction) amplification of a 278-bp fragment of DNA directly from mycelia and sclerotia suspensions of $S$. sclerotiorum without DNA extraction. Lanes 1 and 8: DNA size marker (100-bp ladder); Lane 2: negative control (no DNA or other S. sclerotiorum structures); Lane 3: positive control (S. sclerotiorum); Lanes 4 and 5: suspension of $S$. sclerotiorum mycelia; Lanes 6 and 7: suspension of $S$. sclerotiorum sclerotia. the highest inoculum potential, for the longest soaking period, with probably the highest concentration of compounds released by the seeds. This kind of inhibition in PCR reaction is in accordance with reports by Opel et al. (2009) and agrees with other studies (Williams et al., 2001; Freeman et al., 2002).

The strength of the signal of the PCR product decreased when the infestation level decreased and the soaking time increased (Figures 2 and 3). For the minimum infestation level $(0.25 \%$ or 1 in 400 seeds), the pathogen was detected between 2 and 12 hours of soaking time, but especially between 3 and $7 \mathrm{~h}$. The interference by inhibitor compounds was apparent for the other soaking times (Figure 3G).

For the seeds taken from fields with $80 \%$ (PI80), $50 \%$ (PI-50) and $10 \%$ (PI-10) severity of mold, the mean fungal incidence averaged $14.3 \%, 0.33 \%$, and $0.83 \%$, respectively, across the three incubationbased methods (Table 1). PCR products were amplified for seeds from PI-80 and PI-50, but not for PI-10. In these seed samples, no amplification was found for the longest soaking time $(72 \mathrm{~h})$ for the PI- 80 sample, but it was found between 1 and $12 \mathrm{~h}$ for the PI-50 sample (Table 1).

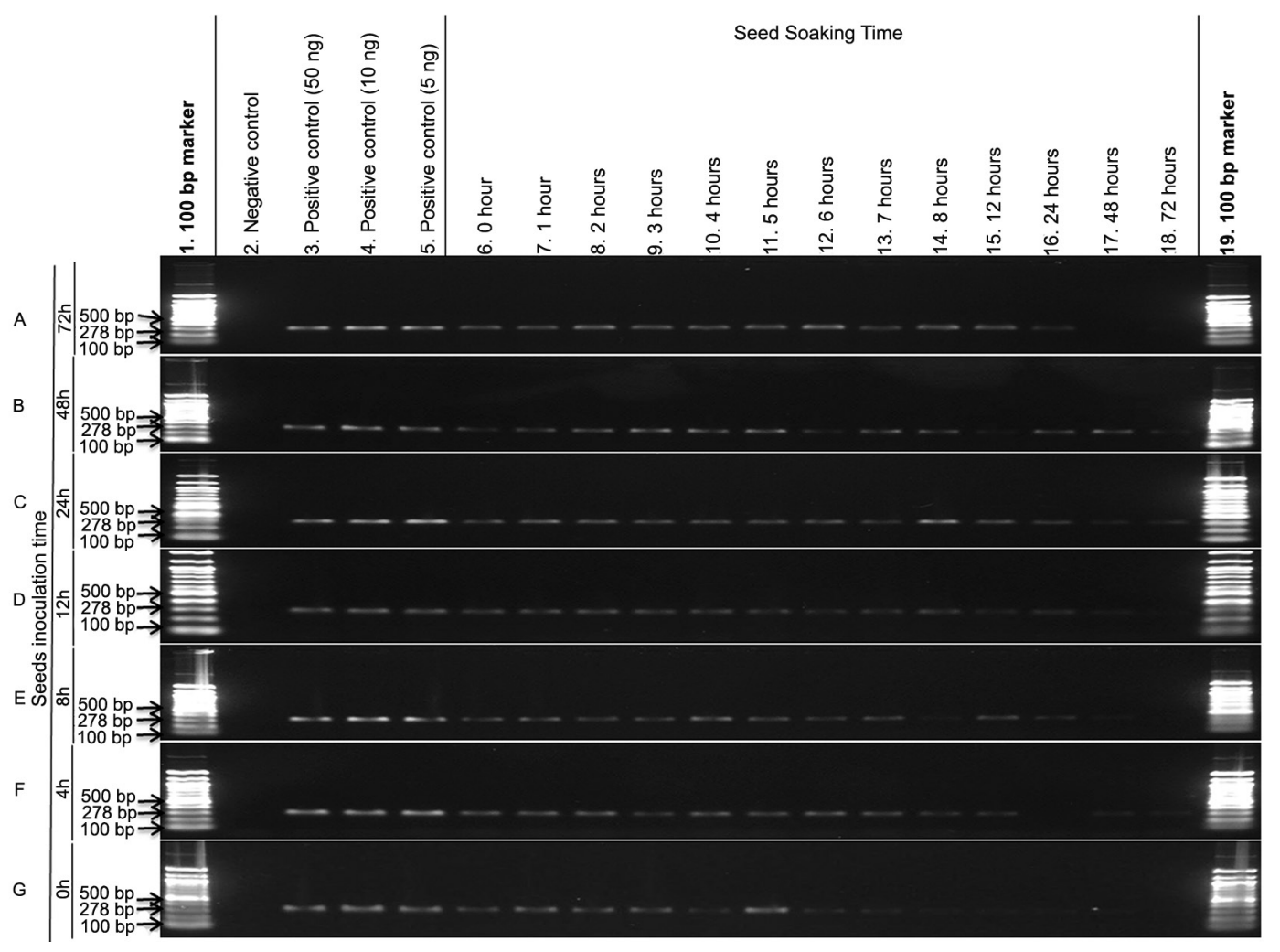

Figure 2 - PCR (polymerase chain reaction) amplification of a 278-bp fragment of DNA directly from seed-soak liquid collected from a seed sample $100 \%$ artificially contaminated by pure culture of $S$. sclerotiorum in PDA dishes for different inoculation times: $72 \mathrm{~h} \mathrm{(A),} 48 \mathrm{~h}(\mathrm{~B}), 24 \mathrm{~h}$ (C), $12 \mathrm{~h}(\mathrm{D}), 8 \mathrm{~h}(\mathrm{E}), 4 \mathrm{~h}(\mathrm{~F})$, and $0 \mathrm{~h}(\mathrm{G})$. Lanes 1 and 19: DNA size marker (100-bp ladder); Lane 2: negative control (water); Lanes 3, 4, and 5: positive control (50, 10 and $5 \mathrm{ng}$ of DNA from S. Sclerotiorum, respectively); Lanes 6 to 18: aliquots from seed-soak liquid collected from different seed-soak times ( 0 to $72 \mathrm{~h}$ ). 
Difficulties associated with PCR inhibitors when using seed-soaking liquid have been reported and they require a DNA extraction step prior to PCR (Audy et al., 1996; Kulik, 2008). Examples of assays that required a DNA extraction step include a real-time PCR assay to detect $S$. sclerotiorum on oilseed rape (Brassica napus L.) petals (Yin et al., 2009) and a qPCR assay to detect airborne $S$. sclerotiorum ascospores (Rogers et al., 2009). Conversely, our seed-soaking based PCR assay (2 to $8 \mathrm{~h}$ of soaking) did not require fungal DNA extrac- tion prior to analysis which made it possible to detect the fungus in seed samples with very low incidence levels $(<0.5 \%)$, both from artificial and natural infestation. Such a short soaking time is an advantage for a seed-health test (Carvalho- Vieira and Machado, 2002). Besides the presence of inhibitory compounds, the very low amount of fungal DNA may limit the detection of the pathogen (Mullis and Faloona, 1987). In our test, a minimum of $10 \mathrm{pg}$ of DNA was required to detect the pathogen (Figure 4).

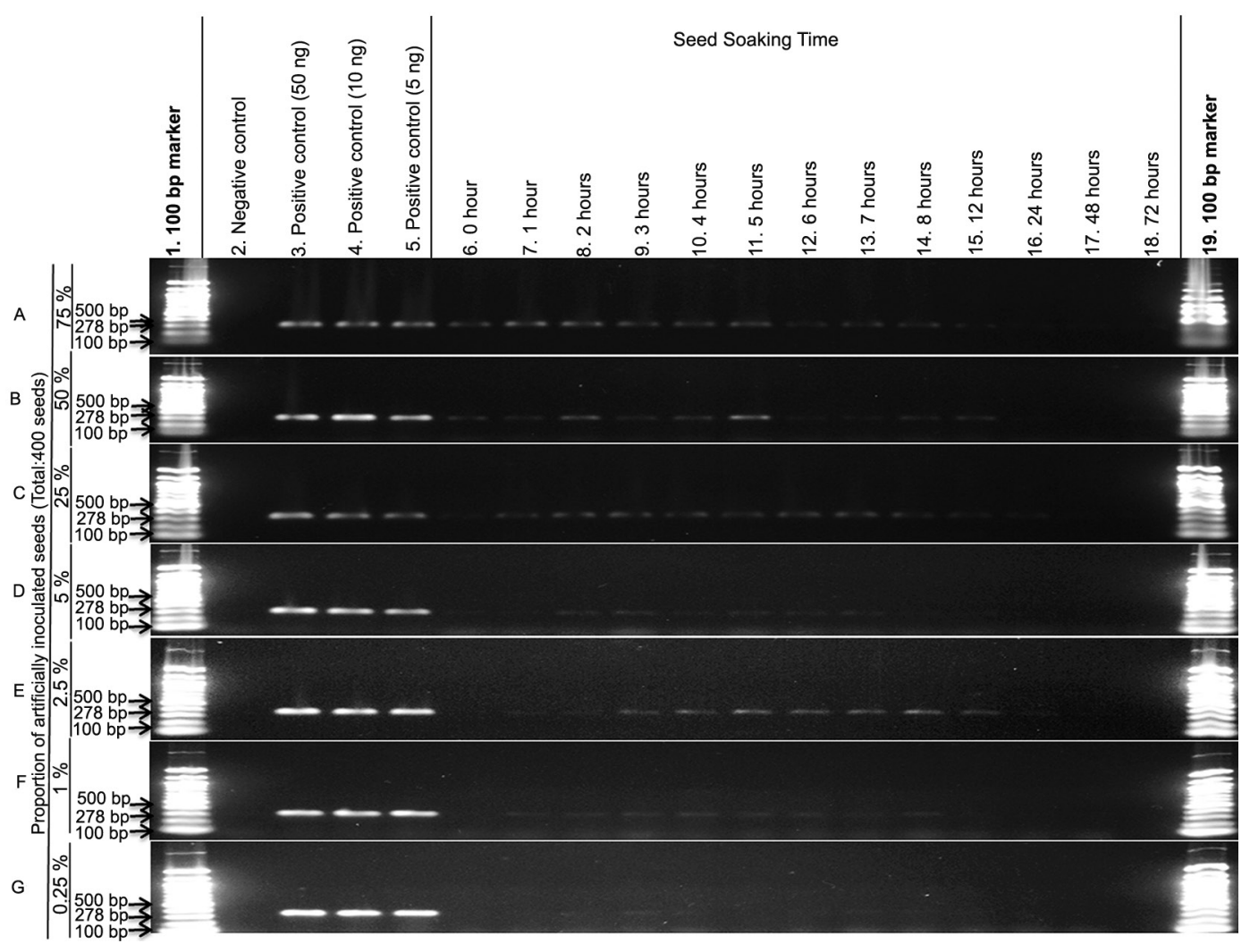

Figure 3 - PCR (polymerase chain reaction) amplification of a 278-bp fragment of DNA directly from seed-soak liquid collected from a seed sample $75 \%(A), 50 \%(B), 25 \%(C), 5 \%$ (D), 2,5\% (E), $1 \%$ (F), and $0.25 \%(G)$ artificially contaminated by pure culture of S. sclerotiorum in PDA dishes for 72 hours. Lanes 1 and 19: DNA size marker (100-bp ladder); Lane 2: negative control (water); Lanes 3, 4, and 5: positive control (50, 10, and $5 \mathrm{ng}$ of DNA from S. Sclerotiorum, respectively); Lanes 6 to 18: aliquots from seed-soak liquid collected from different seed-soak times (0 to $72 \mathrm{~h}$ ).

Table 1 - S. sclerotiorum incidence on the soybean seeds collected from naturally infected plants by the fungus in different disease severities (80, 50 and $10 \%)$.

\begin{tabular}{|c|c|c|c|c|c|c|c|c|c|c|c|c|c|c|c|c|c|}
\hline \multirow{3}{*}{ Sample } & \multirow{2}{*}{\multicolumn{3}{|c|}{ Contaminated seeds on 400 analyzed seeds }} & \multirow{3}{*}{$\underset{* \star}{\mathrm{TCL}}(\%)$} & \multicolumn{13}{|c|}{ PCR-based test } \\
\hline & & & & & \multicolumn{13}{|c|}{ Seed-soaking time (hours) } \\
\hline & Blotter Test & Paper Roll & Neon-S & & 0 & 1 & 2 & 3 & 4 & 5 & 6 & 7 & 8 & 12 & 24 & 48 & 72 \\
\hline $\mathrm{PI}-80 \%$ & 45 & 112 & 15 & 14.33 & $+{ }^{*}$ & + & + & + & + & + & + & + & + & + & + & + & - \\
\hline$P I-50 \%$ & 0 & 1 & 3 & 0.33 & - & + & + & + & + & + & + & + & + & + & - & - & - \\
\hline $\mathrm{PI}-10 \%$ & 0 & 10 & 0 & 0.83 & - & - & - & - & - & - & - & - & - & - & - & - & - \\
\hline
\end{tabular}

${ }^{*}(-)$ No amplicon observed; (+) Amplicon detected; **TCL: Total contamination level: Average of the 1,200 seeds tested, i.e., 400 by Blotter test, 400 by Papel Roll and 400 by Neon-S. 


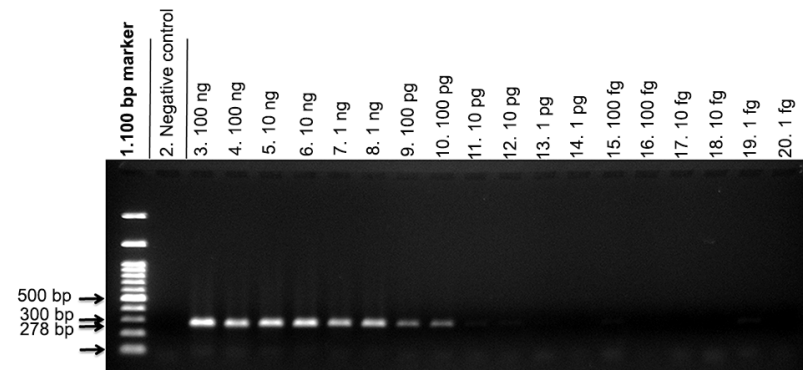

Figure 4 - PCR (polymerase chain reaction) amplification of a 278-bp fragment of DNA of $S$. sclerotiorum from different DNA concentration solutions. Lane 1: DNA size marker (100-bp ladder); Lane 2: negative control (no DNA); Lanes 3 and 4: 100 ng of DNA; Lanes 5 and 6: $10 \mathrm{ng}$ of DNA; Lanes 7 and 8: $1 \mathrm{ng}$ of DNA; Lanes 9 and 10: 100 pg of DNA; Lanes 11 and 12: 10 pg of DNA; Lanes 13 and 14: 1 pg of DNA; Lanes 15 and 16: 100 fg of DNA; Lanes 17 and 18: $10 \mathrm{fg}$ of DNA, and Lanes 19 and 20: $1 \mathrm{fg}$ of DNA.

The present seed-soaking based PCR assay had two major advantages. First, it was highly specific because no other fungi were falsely detected, thus avoiding problems associated with misidentification due to contamination with saprophytic fungi (Freeman et al., 2002; McGee, 2002). Second, the total assay time was significantly reduced (around $9 \mathrm{~h}$ ), compared to incubation-based methods that range from 8 (Neon-S) to 15 days (blotter and paper roll test) (Machado and Langerak, 2002; Taylor et al., 2006; ISTA, 2008). The use of time-effective and accurate methods is critical, especially for pathogens with a high potential for dispersal (Adams and Ayers, 1979; Steadman, 1983; Taylor et al., 2006; Henneberg et al., 2011).

\section{Acknowledgments}

This study was funded by a research grant (064/2008) provided by CNPq (Brazilian National Research Council) and MAPA (Brazilian Ministry of Agriculture). We gratefully acknowledge the assistance of Dr. Fernando C. Juliatti, Dr. João Vida and Dr. Ailton Reis for providing the I-45, I-47 and I-56 isolates, respectively.

\section{References}

Adams, P.B.; Ayers, W.A. 1979. Ecology of Sclerotinia species. Phytopathology 69: 896-899.

Audy, P.; Braat, C.E.; Saindon, G.; Huang, H.C.; Laroche, A. 1996. A rapid and sensitive PCR-based for current detection of bacteria causing common and halo blights in bean seed. Phytopathology 86: 361-366.

Boland, G.J.; Hall, R. 1994. Index of plant hosts to Sclerotinia sclerotiorum. Canadian Journal of Plant Pathology 16: 93-108.

Blakemore, E.J.A.; Reeves, J.C. 2002. Perspectives of the use of modern techniques in seed health testing. p. 19-22. In: Machado, J.C.; Langerak, C.J.; Jaccoud Filho, D.S. Seed-borne fungi: a contribution to routine seed health analysis. ISTA, Bassersdorf, Switzerland.
Brasil. Ministério da Agricultura, Pecuária e Abastecimento. 2009. Handbook of Seed Health Analysis = Manual de Análise Sanitária de Sementes. MAPA-SDA, Brasília, DF, Brazil (in Portuguese).

Carvalho-Vieira, M.G.G.; Machado, J.C. 2002. Applicability of molecular techniques for detection of seed-borne fungi under certification. In: Machado, J.C.; Langerak, C.J.; Jaccoud Filho, D.S. Seed-borne fungi: a contribution to routine seed health analysis. 1ed. ISTA, Bassersdorf, Switzerland.

Fehr, W.R.; Caviness, C.E. 1977. Stages of Soybean Development. Ames: Iowa State University, IA, USA. (Special Report, 80).

Freeman, J.; Ward, E.; Calderon, C.; McCartney, A. 2002. A polymerase chain reaction (PCR) assay for the detection of inoculum of Sclerotinia sclerotiorum. European Journal of Plant Pathology 108: 877-886.

Henneberg, L.; Jaccoud Filho, D.S.; Grzybowski, C.R.S.; Panobianco, M. 2011. Importance of Sclerotinia sclerotiorum detection in soybean seeds = Importância da detecção de Sclerotinia sclerotiorum em sementes de soja. Informativo ABRATES 21: $41-46$ (in Portuguese).

International Seed Testing Association [ISTA]. 2008. Seed health testing. In: International rules for seed testing. ISTA, Bassersdorf, Switzerland.

Jaccoud Filho, D.S.; Lee, D.; Blakemore, E.J.A.; Reeves, J.C. 2002. Demonstration of the use of molecular techniques for detection of Phomopsis species in soya bean seeds. p. 92-110. In: Machado, J.C.; Langerak, C.J.; Jaccoud Filho, D.S. Seedborne fungi: a contribution to routine seed health analysis. ISTA, Bassersdorf, Switzerland.

Jaccoud Filho, D.S.; Dabul, A.N.G. 2011. New methods for detection of fungi in forest seeds $=$ Novos métodos de detecção de fungos em sementes florestais. p. 69-86. In: Santos, A.F.; Parisi, J.J.D.; Menten, J.O.M. Pathology of forest seeds = Patologia de sementes florestais. Embrapa Florestas, Colombo, PR, Brazil. (in Portuguese).

Jiménez-Gasco, M.M.; Jiménez-Díaz, R.M. 2003. Development of a specific polymerase chain reaction-based assay for the identification of Fusarium oxysporum f. sp. ciceris and its pathogenic races 0, 1A, 5, and 6. Phytopathology 93: 200-209.

Juliatti, F.C.; Crato, F.F.; Juliatti, Fa.C.; Couto, K.R.; Juliatti, B.C.M. 2013. Diagramatic scale for the evaluation of white mold on soybean = Escala diagramática para avaliação da severidade de mofo branco em soja. Bioscience Journal 29: 676680 (in Portuguese).

Kulik, T. 2008. Development of a duplex PCR assay for the simultaneous detection of Fusarium poae and Fusarium sporotrichioides from wheat. Journal of Plant Pathology 90: 441-447.

Landa, B.B.; Montes-Borrego, M.; Muñoz-Ledesma, F.J.; JiménezDíaz, R.M. 2007. Phylogenetic analysis of downy mildew pathogens of opium poppy and PCR-based in planta and seed detection of Peronospora arborescens. Phytopathology 97: 1380-1390.

Machado, J.C.; Langerak, C.J. 2002. General incubation methods for routine seed health analysis. p. 48-59. In: Machado, J.C.; Langerak, C.J.; Jaccoud Filho, D.S. Seed-borne fungi: a contribution to routine seed health analysis. ISTA, Bassersdorf, Switzerland. 
McGee, D.C. 2002. Principles, advantages and limitations of seed health testing methods. p. 2-8. In: Machado, J.C.; Langerak, C.J.; Jaccoud Filho, D.S. Seed-borne fungi: a contribution to routine seed health analysis. ISTA, Bassersdorf, Switzerland.

Mullis, K.; Faloona, F. 1987. Specific synthesis of DNA in vitro via a polymerase catalysed chain reaction. Methods in Enzymology 55: 335-350.

Murray, M.G.; Thompson, W.F. 1980. Rapid isolation of high molecular weight plant DNA. Nucleic Acids Research 8: 43214325.

Napoleão, R.; Nasser, L.; Lopes, C.; Café Filho, A. 2006. Neon-S, a new medium for detection of Sclerotinia sclerotiorum in seeds $=$ Neon-S, novo meio para detecção de Sclerotinia sclerotiorum em sementes. Summa Phytopathologica 32: 180182 (in Portuguese).

Opel, K.L.; Chung, D.; McCord, B.R. 2009. A study of PCR inhibition mechanisms using real time PCR. Journal of Forensic Sciences 55: 25-33.

Peltier, A.J.; Bradley, C.A.; Chilvers, M.I.; Malvick, D.K.; Mueller, D.S.; Wise, K.A.; Esker, P.D. 2012. Biology, yield loss and control of Sclerotinia stem rot of soybean. Journal of Integrated Pest Management 3: 1-7.

Rogers, S.L.; Atkins, S.D.; West, J.S. 2009. Detection and quantification of airborne inoculum of Sclerotinia sclerotiorum using quantitative PCR. Plant Pathology 58: 324-331.

Rossen, L.; Norskov, P.; Holmstrom, K.; Rasmussen, O.F. 1992. Inhibition of PCR by components of food samples, microbial diagnosis assays and DNA extraction solutions. International Journal of Food Microbiology 17: 37-45.
Saharan, G.S.; Mehta, N. 2008. Sclerotinia Diseases of Crop Plants: Biology, Ecology and Disease Management. Springer, Berlin, Germany.

Sambrook, J.; Russell, D.W. 2001. Molecular Cloning: A Laboratory Manual. 3ed. Cold Spring Harbor Laboratory Press, New York, NY, USA.

Schrader, C.; Schielke, A.; Ellerbroek, L.; Johne, R. 2012. PCR inhibitors: occurrence, properties and removal. Journal of Applied Microbiology 113: 1014-1026.

Steadman, J.R. 1983. White mold: a serious yield-limiting disease of bean. Plant Disease 67: 346-350.

Taylor, E.; Bates, J.; Jaccoud Filho, D.S. 2006. Diagnosis of seedborne pathogen. p. 649-675. In: Handbook of seed science and technology: Food Product Press Binghamton, NY, USA.

Williams, R.H.; Ward, E.; McCartney, H.A. 2001 Methods for integrated air sampling and DNA analysis for detection of airborne fungal spores. Applied and Environmental Microbiology 67: 2453-2459.

White, T.J.; Bruns, T.; Lee, S.; Taylor, J. 1990. Amplification and direct sequencing of fungal ribosomal RNA genes for phylogenetics. p. 315-322. In: Innis, M.A.; Gelfand, D.H.; Sninsky, J.J.; White, T.J. PCR protocols: a guide to methods and applications. Academic Press, San Diego, CA, USA.

Yang, X.B.; Workeneh, F.; Lundeen, P. 1998. First report of sclerotium production by Sclerotinia sclerotiorum in soil on infected soybean seeds. Plant Disease 82: 264.

Yin, Y.; Ding, L.; Liu, X.; Yang, J.; Ma, Z. 2009. Detection of Sclerotinia sclerotiorum in Planta by a real-time PCR assay. Journal of Phytopathology 157: 465-469. 